\title{
THE ASH'ARI THEOLOGICAL SCHOOL AND THE AUTHORITY OF HUMAN REASON IN ETHICS
}

\author{
Javad Fakhkhar Toosi*
}

\begin{abstract}
This article endeavours to show the compatibility of significant trends in the largest Islamic theological school, namely the Ash'ari, with the authority of reason in ethics. On the one hand, this authority requires reason to understand moral values while, on the other, proving that this authority does not conflict with the creation of actions by God. Ash'arism has accepted the ability of reason to understand moral values, while also accepting practical reason. Moral values and their antithesis are examples of good and evil and can be understood by rational reasoning. Nevertheless, Ash'arism also regards acts as the creation of God, yet without negating the ability of reason to understand good and evil. This article explains the differences between the Ash'arites and Mu'tazilites regarding the authority of independent reason in ethics. The negation of the ability of reason to discern God's acts and commands, thereby accepting the need for religion, has made the Ash'arite theological school unique. Accordingly, religion and reason are the two references in ethics within this school. This article concludes that the authority of reason is compatible with Ash'arism if we base our reading on the view of many prominent Ash'ari scholars. Furthermore, this foundation could be used to study the compatibility of Islam with modern ethical theories.
\end{abstract}

Keywords: Ash'arism; Authority of independent intellect; Ethics; Rational good and Evil; Human Action: Creation by Gods.

\section{Introduction}

When we come to the authority of reason in ethics, we mean accepting the human intellect as a means of recognising moral values, as the only judge of values, and the only conductor and motivor of ethical duties. ${ }^{1}$ It is intended that the intellect should establish moral law so that we can move within our moral compass, without the need for further direction.

We do not want to discuss the various interpretations that exist about the authority of reason in Western thought. This article discusses a significant trend within the largest Islamic school, Ash'arism, that accepts the authority of reason in ethics as a source of moral value. Many Western scholars have 
criticised Islamic ethics as understandable only in the realm of religion. ${ }^{2}$ In other words, there is no moral meaning outside of religion. ${ }^{3}$ They have proposed this critique on the authority of the Qur'an and the tradition of Islamic ethics. ${ }^{4}$ The authority of the Qur'an and Sunnah points towards God as the legislator on moral values, which Western scholars consider to be contradictory with regards to the authority of reason, which renders the human intellect as the lawmaker. ${ }^{5}$ Halstead said: "Islamic ethics does not rely on experience and human intellect." 6 According to him, Islamic morality is based on "obedience" to the Lord and, therefore, knowledge of cause in ethics is unecessary; we carry out moral acts as duties and assignments from God, the promise of reward in paradise or the threat of punishment in hell being the guarantor of the implementation of these duties. ${ }^{7}$

The efforts of Muslim scholars to respond to this critique follow two general approaches. Some scholars have sought to prove the authority of human reason by presenting a series of verses and traditions that emphasise the high position of human reason, such as verses that invite people to reasoning and thinking. For example, the Qur' an says (2:242): "Thus doth Allah make clear His Signs to you in order that ye may understand." ${ }^{\circ}$ Among the scholars who seek to defend reason are N. Davids and Y. Waghid, ${ }^{9}$ as well as T. Ramadan. ${ }^{10}$ But, many commentators describe these verses as invitations to thinking and reasoning in the context of divine revelation and the instructions of the prophets. In this interpretation, human reason is not the lawmaker, but an instrument for understanding the revelations and commands of God.

Further support for the authority of reason within Islam comes from the

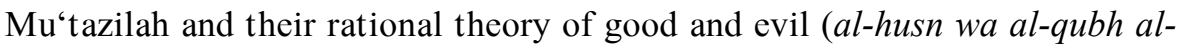
'qliyyan). They found the Ash'ari school to be incompatible with the authority of reason. Among modern works, C. Tan's Rationality and Autonomy from the Enlightenment and Islamic Perspectives also deals with this issue, ${ }^{11}$ as does C. Fraenkel, who compares the Islamic viewpoint with that of the Jews. ${ }^{12} \mathrm{~W}$. Rasch in his Enlightenment as Religion also uses this method. ${ }^{13}$

In this article, we seek to reconcile the authority of reason with prominent and significant trends among the Ash'arites. This is the most common theological school among Muslims and its perceived incompatibility with the authority of reason has been problematic. Nevertheless, we know that there are different tendencies among Ash'ari scholars regarding the authority of human reason. One view accepts the authority of independent reasoning in ethics. This tendency can be called Ash'ari rationalism. This article highlights this reading embodying the authority of reason in ethics. The central point of this approach is to prove that this theological school can be read in such a way that good and evil can be discerned rationally, within the scope of independent reasoning in 
ethics. Also, we shall affirm that the view within this school about the creation of human actions by God does not conflict with the authority of reason.

The importance of this article is clear. First, it introduces a reading from among the Ash'arites themselves that is compatible with the absolute authority of reason, thus refuting conventional interpretations of the Ash'ari as incompatible with human reason. Second, by extension the article shows that affirmation of reason in Islam is not unique to the Mu'tazilah and Shi'a schools. Third, the article provides a forum for dialogue between modernity and crucial areas of Islamic thought.

\section{The Ash`ari View on Rational Good and Evil}

Mu'tazilah theologians, along with the Shi'ah and Maturidi, insist that good and evil are understandable via the human intellect and that actions and objects are inherently good or evil. ${ }^{14}$ For this reason, they do not accept that we need religion to understand good and evil. ${ }^{15}$

The school of Ahl al-Hadith, another dominant theological school, quickly contradicted this theory. ${ }^{16}$ Their objections began with Imam al-Ash 'ari, ${ }^{17}$ who spent a lot of time debating the Mu'tazilah theory of rational good and evil and the role played by human reason in identifying and distinguishing between the two. Imam al-Ash'ari called this issue al-ta'dil wa al-tajwir, ${ }^{18}$ with many subsequent sources also discussing the topic using this title, ${ }^{19}$ including amongst the Mu'tazilah. ${ }^{20}$ His theory is based on two pillars: belief that some things and deeds are good and some are evil, and that human reason is capable of recognising good and evil without external help, such as the goodness of justice and the evil of injustice. ${ }^{21}$

The majority of scholars believe al-Ash'ari considered human knowledge of good and evil to be dependent on revelation. For example, Mohamad Nasrin Nasir, George Makdisi, and Richard Frank, have all followed this path. ${ }^{22}$ Mohamad Nasrin Nasir has argued that the Ash'ari perspective is that man cannot understand good and evil before revelation. ${ }^{23}$ However, George Hourani was the first to raise the possibility that Ash'ari thought could be compared to modern liberal Western philosophy, arguing that Ash'arism does not deny the ontology of the $\mathrm{Mu}^{6}$ tazilah as based on the doctrine of intelligible essences. ${ }^{24}$ It does, however, oppose the Mu'tazilah's stance that ethics constitutes part of this ontology. ${ }^{25}$ Hence, Hourani concluded that Ash'arism considered ethical values as being beyond the understanding of human reason, ${ }^{26}$ a claim repeated in several of his works. ${ }^{27}$ As S. Jackson explained, Ash'ari criticism of the Mu'tazilah concerned the ability of human reason to identify moral 
values, which would make morality dependent on human tendencies. ${ }^{28}$ In this context, Frank quotes Abu Ishaq Isfirayni: "The ethical valuation of actions [is] grounded neither in the acts themselves nor in their properties; they [are] grounded simply in what God says." ${ }^{29}$

In consequence, the conventional interpretation is that the Ash'ari, without any distinction between the different tendencies among them, deny rational good and evil (al-husn wa al-qubh al-'qliyyan). ${ }^{30}$

\section{Ash'arites and the Acceptance of the Intellect's Ability to Understand Moral Values}

In Ash'ari theology, good and evil has three meanings: perfection-deficiency ( $a l$ kamal and al-naqs), suitability-disharmony (al-mulaimah and al-munafirah), and praise-blame (al-madh and al-dhamm). Perfection and deficiency include every value (goodness) or anti-value (evil), whether in actions or in objects. ${ }^{31}$ For example, knowledge is good (perfection) and ignorance is bad (deficiency). Many human behaviours, such as courage or generosity, are considered good or bad in this sense. ${ }^{32}$ Also, and second, something can be good or evil due to its suitability (al-mulaimah) or unsuitability (al-munafirah) with regards to human nature. The third meaning is praise and blame, which two words only describe actions. Accordingly, good means that a person is deserving of praise and reward, while evil deserves blame and punishment. In other words, good is what should be done and evil is what should be left. ${ }^{33}$ Muslim scholars call this kind of rational perception "the command of reason".

The ability of human reason to understand good and evil in terms of the first two of the above meanings is self-evident and confirmed by realities and facts. Among the Ash'arites, most accept this ability. ${ }^{34}$ Fakhr al-Din al-Razi says:

Human reason knows some things as suitable for our soul, and some of them in contrary to it. We do not disagree with the Al-Mu'tazilah in this regard. Since the pleasure and what leads to it is suitable, and the pain (suffering) and what leads to it is contradistinction to our nature. Furthermore, there is no need to know this suitability and disharmony from the Shariah. Moreover, we know with our reasons that, knowledge is perfection, and ignorance is a defect. ${ }^{35}$

Al-Jurjani, another Ash'ari thinker, says:

All the wise people are committed to being abused in injustice, 
harmful lying, the trinity, and unjust killing [of] the Prophets. They also affirm that justice, useful veracity, faith and infallibility of the Prophets are good. The assertion of the evil or the good in these cases is not based on shariah. The non-believer like Brahmanism believe in that. Moreover, [this] is not based on custom, the customs are different regarding their nations. We see all people are the same in this belief. All the wise people are committed to good and evil in this sense (suitability and disharmony). There is no dispute between us since we accept that they are rational. ${ }^{36}$

We see this sentiment again in al-Taftazani. ${ }^{37}$ Thus, among the three meanings of rational good and evil, these Ash' ari scholars share the Mu'tazilah view with regards to the first two and therefore believe in the rationality of good and evil.

The third meaning, however, is where Ash 'ari and $\mathrm{Mu}^{\text {'t }}$ azilah scholars differ. But we will see that this opposition does not contradict an acceptance of the authority of reason in ethics. For the moment, we are content that acceptance of rational good and evil in the first two meanings implies acceptance of the ability of reason to understand moral values. Perfection and deficiency (the first meaning) have a general scope. In the field of ethical behaviour, perfection is equivalent to virtue and value, while deficiency is equivalent to vice and immoral behaviour. Muslim scholars have explicitly stated that moral values are examples of the first meaning of good and vices are examples of the first meaning of evil. ${ }^{38}$ Therefore, if we believe in the ability of reason to understand perfection and deficiency, we must consider it capable of understanding moral values and vices.

The second meaning of good and evil, namely suitability and disharmony, also includes moral values. Muslim scholars have defined suitability as maslihah and disharmony as mafsidah. For example, al-Qushji said: "Sometimes good and evil is also termed as interest and damage, and they say that good is something preferable, and evil is something which damages." 39 There are numerous examples where moral values are examples of perfection and suitability and their antithesis are examples of deficiency and disharmony.

One who reads this debate should note that Ash'arites do not accept inherent good and evil. ${ }^{40}$ When some Ash'aris speak of the inability of reason to understand good and evil, they mean the intrinsic type since, as we have seen, they explicitly accept the ability of reason to understand good and evil in general. ${ }^{41}$ Some opponents of Ash'arism have concluded, however, that the movement accepts that no fixed and intrinsic moral values are understandable to human reason. The eminent Ash'ari view, however, believes in the rational 
nature of good and evil with regards to perfection-defection and suitabilitydisharmony. Everything that is understood by human reason does not change with different customs, wills, and tastes. Thus, the Ash'ari view accepts the consistency of at least some moral values. ${ }^{42}$

In the third meaning of good and evil, namely something that deserves praise or blame (al-madh or al-dhamm), Ash'ari scholars do not consider good and evil to be compatible. It is not possible for good and evil to be gathered in one place; someone who says 'I will lie tomorrow' and does so will see good and evil come together because his statement will be true (good) while at the same time a lie (evil). ${ }^{43}$ Ash' ari scholars consider good and evil to be causes (al-muqtadi) that depend on circumstances. This causality may not be active in some situations and conditions. ${ }^{44}$

The third meaning of good and evil refers to something that deserves praise or blame and relates to ethical actions $\left(a f^{\prime} a l\right)$, not moral values. Ash'arites tend to deny intrinsic good and evil. Thus, relativity applies only to ethical acts and not moral values and, therefore, in some situations, even if lying is good and telling the truth is not, honesty as an ethical value has not changed. Ash'ari scholars distinguish between ethical values and ethical verbs.

\section{The Ash 'ari School and the Ability of Human Reason to Legislate in Ethics}

The most prominent role reason plays in morality is as the creator of ethicsthat we have to follow the law established by reason. The opponents of the Ash'arites believe this school accepted the ability of reason when understanding good and evil but not in the context of legislation.

Researchers have divided reason into two types: theoretical and practical. The first pertains to what can be known from the realm of human desire and power. This kind of cognition is related to worldview and is therefore called theoretical reason. The second deals with the realm of human will and authority - that is, with the voluntary actions of man. This kind of rational cognition, which is related to actions and behaviour, is called practical reason. ${ }^{45}$

A group of Ash' arites believed that theoretical reason recognises good and evil. Theoretical reason is related to "is", while practical reason pertains to "ought". ${ }^{46}$ The authority of theoretical reason with regards to good and evil is apparent because perfection and deficiency exist outside the mind. As such, they are related to "is". Also, rational recognition is about something that exists outside the mind and is either compatible or incompatible with the soul. 
As such, the subject relates to "is". In these two meanings, reason does not command anything, but only recognises something.

However, moral action exists in the realm of practical reason. Ethics talks about "have to" or "should not". ${ }^{47}$ Ethics seeks to adorn one with virtue and values. Morality is related to behaviour and actions. Until what is theoretical has entered the realm of practical reason, and the necessity of doing or abandoning something has been grasped by reason, no moral law has been enacted. ${ }^{48}$

Those Ash'arites who accepted the ability of reason to understand good and evil in its first two meanings (perfection-deficiency and suitabilitydisharmony) also accepted that practical reason commands the perception of theoretical reason. This argument rests on a consideration that practical reason orders us to do or not do something in three cases:

1. When it finds that something is perfect or deficient; ${ }^{49}$

2. When it finds something is suitable or inappropriate for the human soul ${ }^{50}$

3. When a human trait and its implications are taken into consideration by practical reason. For example, courage or benefaction (khiyr) persuades practical reason to command an act according to its compatibility with those traits. ${ }^{51}$

In the first and second cases, practical reason follows the diagnosis of theoretical reason. The first two cases are where the Ash'arites accept the ability of theoretical reason. In these two cases, there is a practical command and Ash'arites do not deny the command of practical reason in these two cases. This contradicts the opponents of Ash'arism, including the Shi' ah and Mu'tazilah, who have reported that Ash'ari theology accepts the perception of theoretical reason but does not accept the command of practical reason when doing or refusing to do an act. ${ }^{52}$

It is now time to examine the roots of the dominant perception of the Ash'ari school-namely, that it opposes rational good and evil (the basis of the authority of reason in ethics). Despite the acceptance of the theory of good and evil by Ash'arites, they differ with the Mu'tazilah view, leading to the emergence of the above perception. We will make it clear that any objections the Ash'ari have to the Mu'tazilah in no way effects the authority of reason in ethics. 


\section{The Ash'ari View on the Creation of Human Actions by God and the Authority of Independent Reason}

In this section, we will show that the Ash' ari view on the ability of the human intellect to understand moral values does not conflict with the creation of actions by God.

\section{The Creation of Human Actions by God according to the Ash 'arites}

The Ash'arites believe that human actions are created by God. This view is based on the fact that all events and acts are created by the Will of God. ${ }^{53}$ According to this view, what we consider to be the cause of events and acts are not in fact so; only God constitutes a causal factor. To illustrate this, Qadi 'Ad al-Din al-'Iji, in his book al-Mawaqif fi 'ilm al-kalam, states:

The acts of men come only with the power of God, and human power does not have an effect on the realisation of those things. God creates the power and the will in man, which, if there is no obstacle, God, at the same time as human power and will, creates the act. Therefore, what a man does, is God's creation and is acquired by man. The meaning of the theory of 'Gain' (al-kasb) is that, the act will be done simultaneously as human power and will, but human power and will, have no effect on the emergence of the act. This is the theory of shiykh [sic] Abu al-Hasan al-Ash'ari.

Some Ash 'arites consider the theory of rational good and evil to conflict with human action as the creation of God. According to them, we cannot consider what a person does to be either good or bad if that act was created by God. ${ }^{54}$

\section{Contradiction with Good and Evil or with the Ability of Reason?}

By analysing the view of Ash'arites on the creation of human actions by God, we find this view is inconsistent with intrinsic good and evil, not with the ability of the human intellect to discern good and evil. As we have seen, Ash'arites accept the existence of fixed moral values and that the good and evil of moral actions vary based on situation, conditions, circumstances, and external factors. This means that human actions cannot be inherently good or bad, but are good or bad under the influence of external factors and other incidental things. The result is that Ash'ari theology is balanced, without any incompatibility in its components. 
According to the Ash'arites, all human actions are created by God. But if good and evil exist in the substance and essence of an act, these cannot be created by God since He does not create evil. Equally, if evil is something added to the substance and essence of a human act, the same problem remains as that evil will remain either an attribute of the act or not. In that case, we have three options: 1 . evil is not an attribute of the act (but then reason cannot understand it); 2. evil is an existing attribute (but then, when applied to a good act, becomes an attribute of a non-existent thing); or 3. evil is a non-existent attribute (but something non-existent cannot be applied to something existent). These problems only emerge, however, when we consider good and evil as intrinsic. If we do not do so, they cease to exist. ${ }^{55}$ Thus, the Ash'ari view does not contradict the foundation of good and evil.

In their view, the creation of actions by God is only contrary to the notion of inherent good and evil, not to the ability of the human intellect to understand good and evil. The issue is that God's deeds are always good so, if we believe human activity is created by God, human actions must also always be good. So, how do we characterise some human actions as wrong or bad? In response, the Ash'arites utilise the theory of gain (kasb). Ash'arites believe that good and evil are related to kasb and not to divine creation.

In brief, kasb means the simultaneity of independent human action with the creation of the ability to act by God. For example, when someone choose to walk, at the same time God creates the action of walking in human beings. There are various interpretations of this theory. Al-Ghazali considers the power of mankind within this context to be totally unproductive. ${ }^{56}$ Al-Taftazani's view, on the other hand, is that God creates power when a human is going to act. ${ }^{57}$ The difference between him and al-Ghazali is that, according to alTaftazani, human kasb is the intention to do an act while al-Ghazali considers the power of humanity to be totally ineffective. Bagilani believes that human actions are created by God, but the titles of those acts (that is, the subject of divine commands) are created by humans. ${ }^{58}$ According to al-Juwini, God creates power in humans and actions are then created by that power. ${ }^{59}$ We do not want to present a detailed discussion of this theory or judge between these interpretations, but the author believes that the interpretation of al-Juwini is consonant with the thought of Imam Ash'ari, who wrote:

$$
\text { حقيقة الكسب ان الشئ وقع من المكتسب به بقوة محدثة } 60
$$

Regardless of the interpretations that have been made, this theory links the idea of rational good and evil on one side with the theory of the creation of actions by God on the other. Because it eliminates the polarising readings of good and evil 
and the creation of actions by God, the theory of kasb proves that attributions of good and evil to an action can be based on acquisition. Therefore, it does not mean dividing and describing divine deeds as good or evil.

The Ash'arites also compared good and evil with other traits, while raising the question of whether, if the creator of human actions be God, we can define human actions as known (al-m 'lum), possible (al-mumkin), feasible (al-maqdur), or the like while not being able to classify them as good or evil. In response to this question, the Ash'arites explained attributes like good and evil as being not intrinsic, but connected to the circumstances, factors and situations of an act. ${ }^{61}$ Perhaps we cannot find a clearer explanation than al-Taftazani's, who says in his famous book Sharh al 'aqaiyd al-Nasafiyah: "The good and evil of human acts, are two things that God creates knowing them in man's mind".

Hence, Ash'ari theology rejects the intrinsic nature of good and evil but is not opposed to the rational understanding of good and evil. As such, this school does not conflict with the authority of independent human reason in ethics.

\section{The Uniqueness of the Ash'ari Theological School on the Authority of Reason in Ethics}

The Ash'ari school shares with the Mu'tazilites the opinion that reason can perceive good and evil. There are differences, however, that make this school unique, the result of which is a balanced theory that maintains the authority of reason in morality.

\section{God's Commands and Deeds are not with in the Scope of the Intellect}

The Ash'ari School believes that reason cannot determine what solicits God's praise and salvation (reward in the world to come) or His punishment (torment in hell). In consequence, their opponents accuse them of denying humanity's ability to reason. This school only opposes, however, the rational understanding of divine acts and orders. ${ }^{63}$ As al-Taftazani says:

This topic has been discussed among the issues related to the acts of God, although Al-Ash'ariyyah denies rational good and evil in divine acts. The reason is that the opposing side of the discussion, namely, Al-Mu'tazilah, has expanded the topic to acts of Allah. We have put the discussion here, to demonstrate their belief in this regard and our view on it. ${ }^{64}$ 
Also, Imam al-Ash'ari, in his Kitab al-Luma', proposed al-ta'dil wa al-tajwir as the sequel to the debate on istita' $a h$ and kasb, highlighting the relationship of the topic to divine actions. ${ }^{65}$ All the issues Imam al-Ash'ari raised on this topic were connected to the acts of God.$^{66}$ What Ash'aris have since articulated on this issue demonstrates that they only deny rational good and evil in the field of God's acts. For example, contrary to Mu'tazilite thought, they regard good as the effect and result of divine acts and His orders ${ }^{67}$ Prominent Ash 'ari scholars argue that when a case does not relate to religion but human affairs, practical reason orders the performance or abandonment of an act in accordance with its level of merit or blame. ${ }^{68}$

Moreover, the basis of Ash'arite arguments is that human reason cannot understand God's commands and acts. They believe in God as the owner of the world, so that nothing can limit His power and authority. ${ }^{69}$ They argue that Qur' anic verse 17:15, "nor would We punish until We had sent a messenger", ${ }^{70}$ indicates a focus on religious law and the deeds of God. ${ }^{71}$ Thus, by divine decree lying is not always bad but obligatory (as when saving the life of the Prophet), as is killing (when performed as a religious punishment). ${ }^{72}$

The most crucial argument in the Mu'tazilite School is that all peoples, regardless of religion or nation, understand the goodness of justice ( $a d l)$ and beneficence (khir), just as they know the deficiencies of injustice (zulm) and ignorance $(j a h l)$. Even unbelievers and atheists can accept these cases as good and evil. In response to this argument, al-Taftazani relates these notions to the first two meanings of good and evil (above). Accordingly, people find good and evil in such things because they have experienced justice and beneficence to be suitable or perfect for human nature, just as they found injustice and ignorance to be deficient and unsuitable. ${ }^{73}$ This response shows that Ash' ari scholars only deny rational good and evil in the context of divine commands and actions.

\section{The Need for Religion in Ethics}

According to Ash 'arites, only in the field of human actions can reason understand perfection-deficiency and suitability-disharmony. These four concepts are equivalent to moral values and their opposites. Ash 'arites therefore accept the applicability of reason in the fields of ethics and moral values, but without denying the need for religion in ethics also. These scholars accept the authority of reason and religion together in the field of ethics.

Ethics pursues two main goals. First, it familarises humanity with the values regulating their relationship with God and the supernatural (ghayb). This is considered a cause of human happiness in the afterlife and, therefore, pertains 
to metaphysics and the Day of Resurrection. Islamic worship is a significant example of this part of ethics; reason cannot understand the effects of worship, such as prayer (salah) or fasting (siyam), in the Hereafter. We need religion and its guidance to explain how our behaviour affects our life after death and our relationship with God. Second, ethics helps humanity deal with the moral values associated with this worldly life and the provision of its happiness. When we speak of the worldly life, we speak of a wide range of human relationships. Human reason can be fully developed in the context of ethical values and behaviour, and work for the prosperity of this world by making us moral beings.

The Ash 'ari trend under discussion here recognises the authority of reason only in the context of worldly ethics. This allows for the authority of an independent intellect, along with the authority of religion. This is seen in discourses about ethical conscience, where the latter is introduced in the same sense as scholars today understand it, as an institution within a person that encourages them to perform good deeds and reject evil. ${ }^{74}$ The Quran says: "And I do swear by the self-reproaching soul [conscience]"75 and "By the Soul, and the proportion and order given to it; And its inspiration as to its wrong and its right". ${ }^{76}$ From these passages it is clear that God has given human beings the power to recognise good and evil. Also, the Prophet said to a man named Wabisah: “'Have you come to ask me about good and evil?' The man said: 'yes'. The Messenger gathered his hand and calmly put it on the man's chest and said: 'Ask your soul! Ask yourself in your heart' (it is repeated three times), the good is that [which] your soul commands and [which is] accepted by your heart, and evil is to affect your soul (that is, your soul will dislike it)." 77 In another tradition, the Prophet said in similar words: "The duty (taklif) is something that was in the hearts of the people, then the Qur'an came, and people found what they had in their hearts [was] in the Qur'an."78

Thus, the compatibility of the Ash'ari School with the authority of human reason is illustrated. This provides grounds for accepting this authority amongst followers of this Islamic theological school.

\section{Conclusion}

In this article, we have discussed the authority of reason in Islamic ethics from the prominent Ash'ari perspective. As a first step, we demonstrated that Ash'arites accept the theory of rational good and evil (al-husn wa al-qubh al'qliyyan). They believe that good and evil have three meanings: perfectiondeficiency, suitability-disharmony, and praise-blame. Perfection and suitability have many examples which, in ethical terms, are moral values. Deficiency 
and disharmony, on the other hand, are examples of vices. Belief in the ability of reason to understand perfection-suitability and defection-disharmony substantiates its ability to also understand moral values. Ash'arites also allow reason to legislate in the field of ethics. This refers to the command of practical reason in accordance with perceived ethical values.

As a second step, we examined the authority of reason in ethics from the Ash'arite point of view concerning the creation of human actions by God. Ash 'arites consider the creation of actions by God to be contrary to the notion of inherent good and evil, but not the principle of good and evil. The theory of kasb shows that Ash'arites accept the division of actions into good and evil based on human intervention while acknowledging the ability of reason to understand these conepts. Thus, Ash'arites accept the creation of actions by God, the ability of the intellect to perceive good and evil, and, consequently, the authority of reason in ethical matters.

Our last step explained the need for religion in ethics; the Ash 'ari view does not negate the need for religion, despite accepting the authority of independent reason in ethics.

We conclude our article with the following policy recommendations:

- Ash'arism has the capacity to deal with the authority of independent reason, allowing it to adapt to modern moral theories. The current article recommends that more studies examine modern ethical theories and their elements based on Ash'arism.

- The aspects of Ash'ari thought examined here should be incorporated into modern Islamic studies by contemporary followers of the Ash'ari School. Its significance should not be undervalued.

- In-depth research be conducted into the differences between Ash'ari rationalism and $\mathrm{Mu}^{\text {'tazilah rationalism. }}$

\section{Notes}

* Javad Fakhkhar Toosi, Department of Islamic Education, Academy of Islamic Studies, University of Malaya, Kuala Lumpur, Malaysia. Email: j.fakhar.t@ gmail.com

1. Jean E Hampton, The Authority of Reason (Cambridge: Cambridge University Press, 1998).

2. James Rachels and Stuart Rachels, The Elements of Moral Philosophy, vol. 119 (New York: McGraw-Hill, 1993). 
3. Ahmad Achrati, 'Deconstruction, Ethics and Islam,' Arabica 53, no. 4 (2006).

4. J. Mark Halstead, 'Islamic Values: A Distinctive Framework for Moral Education?' Journal of Moral Education 36, no. 3 (2007).

5. Carlos Fraenkel, 'Theocracy and Autonomy in Medieval Islamic and Jewish Philosophy,'Political Theory 38, no. 3 (2010).

6. Halstead, 'Islamic Values,' 12.

7. Ibid.

8. Abdullah Yusuf Ali, The Holy Qur'an Translated (Median: Dar al-Quran, 1980), 39.

9. Nuraan Davids and Yusef Waghid, 'The Quran and Individual Autonomy,' in Ethical Dimensions of Muslim Education (London: Palgrave, 2016).

10. Tariq Ramadan, Radical Reform: Islamic Ethics and Liberation (Oxford: Oxford University Press, 2009).

11. Caroline Tan, 'Rationality and Autonomy from the Enlightenment and Islamic Perspectives,' Journal of Beliefs \& Values 35, no. 3 (2014).

12. Fraenkel, 'Theocracy and Autonomy.'

13. William Rasch, 'Enlightenment as Religion,' New German Critique no. 108.

14. Mas'ud ibn 'Umar al-Taftazani, Sharh al-Maqasid (Qom: Sharif Razi Publishing House, 1988), 2, 282.

15. Ibid.

16. Muhammad ibn 'Abd al-Karim al-Shahrastani, al-Milal wa al-Nihal (Beirut: Dar al-kutub al-'ilmiyah, 1992), 1, 235.

17. 'Abd al-Rahman ibn Khaldun, al-'Ibar wa-diwan al-mubtada'wa-al-khabar fi ayyam al-'arab wa al-'ajam wa al-barbar wa man 'asarahum min dhawi alsultan al-akbar (Beirut: Dar Ihya' al-Turath al-'arabi, 1988), 1, 464.

18. Abu al-Hasan al-Ash'ari, al-Luma' fi al-Radd 'ala Ahl al-Zaygh wa al-Bida, (Cairo: Maktabah al-azhariyyah lil turath, n,d.), 114.

19. Siyf al-din al-Amidi, Abkar al-Afkar fi Usul al-Din (Cairo: Dar al-Kutub, 2001), 2, 115; Al-Juwayni, al-Irshad Ila Qawati ' al-Adillah fi Usul al-I'tiqad (Beirut: Dar al-Kutub al-'Ilmiyyah, 1996), 107.

20. Qadi 'abd al-Jabbar al-Mu'tazli, al-Mughni fi Abwab al-Tawhid wa al-'Adl (Beirut: Dar al-Kutub al-'Ilmiyyah, 2011), 6, 3.

21. Al-Taftazani, Sharh al-Maqasid, 2, 282.

22. Mohamad Nasrin Nasir, 'The Concept of Taklif According to Early Ash'arite Theologians,'Islamic Studies 55, no. 3/4 (2016); George Makdisi, 'Ash'ari and the Ash'arites in Islamic Religious History I,' Studia Islamica no. 17 (1962); Richard M. Frank, 'Moral Obligation in Classical Muslim Theology,' The Journal of Religious Ethics 11, no. 2 (1983).

23. Nasrin, 'The Concept of Taklif,' 293.

24. George F. Hourani, 'Two Theories of Value in Medieval Islam,' The Muslim World 50, no. 4 (1960): 269-70.

25. A. Kevin Reinhart, Before Revelation: The Boundaries of Muslim Moral Thought (Albany: SUNY Press, 1995).

26. Sherman A. Jackson, 'The Alchemy of Domination? Some Asharite Responses to Mutazilite Ethics,' International Journal of Middle East Studies 31, no. 2 (1999): 186.

27. George F. Hourani, 'Averroes on Good and Evil,' Studia Islamica no. 16 (1962): 
17.

28. Jackson, 'The Alchemy of Domination?' 187.

29. Frank, 'Moral Obligation in Classical Muslim Theology,' 208.

30. Hasan ibn Yusuf ibn Mutahhar al-Hilli, Nahj al-Haqq wa Kasf al-Sidq (Beirut: Dar al-Kitab al-Lubnani, 1982), 161.

31. Al-Taftazani, Sharh al-Maqasid, 4, 282.

32. Ibid.

33. Ibid.

34. Ibid. 4, 283; Ali ibn Muhammad al-Jurjani, Sharh al-Mawaqef (Tehran: Sharif Reza Publishing House, 1992). 8.192

35. M. Fakhr al-Din al-Razi, al-Arba'in fi Usul al-Din (Cairo: Maktabah alAzhariyyah, 1986), 1, 346.

36. Al-Jurjani, Sharh al-Mawaqef, 8, 192.

37. Al-Taftazani, Sharh al-Maqasid, 4, 282.

38. 'Ali ibn Ahmad ibn Hazm, al-Fisal fi al-Milal wa al-Ahwa' wa al-Nihal (Beirut: Dar al-Kutub al-'Ilmiyah, 1996), 3, 261.

39. Ali ibn Muhammed al-Qushji, Sharh al-Jadid Ala Tajrid al-I'tiqad (Qom: Sharif Radi Publishir, n,d.), 157.

40. Al-Amidi, Abkar al-Afkar, 2, 117.

41. Al-Taftazani, Sharh al-Maqasid, 4, 288.

42. Some opponents of the Ash'ari school believe in the malleability of suitability and disharmony based on customs and tastes, see Muhammad Rida Al-Muzaffar, Usul al-Fiqh (Qom: Iran Islamic Publishing Corporation., 2009), 2, 276.

43. Al-Taftazani, Sharh al-Maqasid, 2, 117.

44. Al-Amidi, Abkar al-Afkar, 2,117.

45. Ibid. 1, 128.

46. Al-Jurjani, Sharh al-Mawaqef, 7, 211.

47. Garrett Cullity and Berys Gaut, Ethics and Practical Reason (Oxford: Clarendon Press, 1997), 124.

48. Ibid., 73 .

49. M. Fakhr al-Din al-Razi, Mabahith al-Mashriqiyyah fi 'Ilm al-Ilahiyyat wa alTabiyyat (Qom: Bidar Publication, 1990), 1, 351-4

50. Ibid. 1, 104.

51. Al-Muzaffar, Usul al-Fiqh, 2, 281.

52. Ibid. 2, 206.

53. Muhammad ibn Umar Fakhr al-Din al-Razi, al-Barahin fi 'Ilm al-Kalam (Tehran: University of Tehran, 1962), 268.

54. Al-Jurjani, Sharh al-Mawaqef, 8, 163.

55. Al-Amidi, Abkar al-Afkar, 2, 125.

56. Muhammad ibn Muhammad al-Ghazali, al-Iqtisad fi al-I'tiqad (Beirut: Dar AlKutub Al-'Ilmiyyah, 1989), 60.

57. Al-Taftazani, Sharh al-Maqasid, 4, 225.

58. Al-Shahrastani, al-Milal wa al-Nihal, 1, 97.

59. Ibid. 1, 98-9

60. Al-Ash`ari, al-Luma` fi al-Radd, 76.

61. Al-Amidi, Abkar al-Afkar, 2, 126.

62. Sa'ad al-Din Masud ibn Umar Al-Taftazani, Sharh al-'Aqaiyd al-Nasafyah 
(Cairo: Maktabah al-Kulliyyat al- Azhariyyah, 1987), 16.

63. Al-Amidi, Abkar al-Afkar, 2, 113.

64. Al-Taftazani, Sharh al-Maqasid, 4, 282.

65. For a study of istita'ah and kasb, see Muhammad bin al-Hasan bin Furak, Maqalat al-Shiykh Abu al-Hasan al-Ash'ari Imam Ahl al-Sunnah (Cairo: Library of Religious Culture, 2005).

66. Al-Ash'ari, al-Luma' fi al-Radd, 114-22.

67. Al-Taftazani, Sharh al-Maqasid, 4, 283.

68. Ibid., 4, 282.

69. Al-Ash'ari, al-Luma' fi al-Radd, 116-7.

70. Ali, Holy Qur'an, 283.

71. Al-Taftazani, Sharh al-Maqasid, 4, 285.

72. Ibid.

73. Ibid. 4, 291.

74. Giuseppina Iacono Lobo, 'John Milton, Oliver Cromwell, and the Cause of Conscience,' Studies in Philology 112, no. 4 (2015).

75. Ali, Holy Qur'an, 577.

76. Ibid., 595.

77. Ahmad ibn Hanbal, al-Musanad (Beirut: Dar Ihya' al-Turath al-'Arabo, 1991), 4, 228.

78. Abu 'Abd Allah Muhammad ibn Isma'il al-Bukhari, Sahih al-Bukhari (Lebanon: Dar al-Fikr, 1981), 8, 188. 